\title{
A CASE OF E. COLI MENINGITIS TREATED WITH SYSTEMIC AND INTRATHECAL AMPICILLIN
}

\author{
Constance R. Spittle, M.B., B.S. \\ Lecturer in Clinical Pathology, Medical School
}

\author{
B. M. Phillips, * M.B., M.R.C.P. \\ Medical Registrar to the Neurosurgical Unit
}

\author{
St. George's Hospital, S.W.I
}

THE following case is of interest in that it illustrates the effectiveness of a new penicillin derivative, ampicillin ('Penbritin ') (6 D (-) $\alpha$-amino-phenylacetimido penicillanic acid) which is active against a number of Gram-negative as well as Grampositive organisms. Preliminary reports on Penbritin appeared in the British Medical fournal on July 22, 196r (Rolinson and Stevens, Brown and Acred, Knudsen, Rolinson and Stevens, Stewart, Coles, Nixon and Holt).

\section{Case Report}

On 28/4/6I a 17-year-old American airman was admitted to St. George's Hospital Neurosurgical Unit under the care of Mr. Wylie McKissock. Five hours prior to admission he had been struck a glancing blow over the left temporal region by a $600-1 b$. weight. Immediately following the injury he was unconscious for a short period and made no response to painful stimuli.

At the time of admission he was stuporose and not obeying commands. General physical examination revealed no abnormality of the cardiovascular, respiratory or alimentary system and the blood pressure was $160 / 90 \mathrm{~mm}$. Hg.

There was extensive bruising over the left temporal region with a hæmatoma in the left side of the neck, between the angle of the mandible and the anterior border of the upper third of the sternomastoid. Bloodstained cerebro-spinal fluid was issuing from the left nostril and there was blood in both external auditory meati. The pupils were equal and reacted briskly to light. The left eye was depressed below the horizontal and there was obvious limitation of gaze. On examination of the limbs he was found to have a complete right hemiplegia.

$\mathrm{X}$-ray of the skull showed a linear fracture in the right temporal bone extending into the petrous part of the temporal bone.

A left carotid arteriogram showed complete occlusion of the internal carotid artery just before it entered the skull.

In the absence of clinical evidence of a compressing lesion, barrier nursing under prophylactic antibiotic cover was instigated. One megaunit of soluble penicillin and sulphadiazine I g. six-hourly were given along with phenobarbitone $30 \mathrm{mg}$. t.d.s.

Over the first 24 hours following the injury his level of consciousness improved and he began to move his right limbs spontaneously. The leakage of CSF, however, persisted from the left nostril. By $1 / 5 / 6$ I there had been further improvement of his hemiparesis and he was giving a verbal response. On 9/5/6 I the CSF was under a normal pressure, the fluid being

* Present address: National Hospital for Nervous Diseases, Queen Square, London, W.C.I. xanthochromic with no excess of cells and $70 \mathrm{mg} /$ $100 \mathrm{ml}$. of protein. The cerebro-spinal rhinorrikea persisted and on 13/5/61 he became pyrexial. Orer the next two days the fever persisted and he became irritable, with nuchal rigidity. Lumbar puncture $\overline{\text { on }}$ r 5/5/6r showed 6,000 white cells, mainly polymorposs, and the sugar content was $25 \mathrm{mg}$. $/ 100 \mathrm{ml}$. A perre growth of $\boldsymbol{E}$. coli was obtained, the organism befog sensitive to streptomycin ( $80 \mu \mathrm{g}$.), kanamycin ( $3 \circ \mu \mathrm{g}$.) and neomycin ( $3 \circ \mu \mathrm{g}$.). Treatment was commenced with streptomycin $0.5 \mathrm{~g}$. six-hourly and chloramphenicoll $0.5 \mathrm{~g}$. six-hourly, until the $20 / 5 / 6 \mathrm{I}$, but without impro ment in the clinical state, and the cell count remained at $\mathrm{r}, 800 / \mathrm{cu} . \mathrm{mm}$. E. coli was again cultured from $\mathrm{Be}_{\mathrm{e}}$ CSF. In view of the report on the sensitivity of the organism, kanamycin $0.5 \mathrm{~g}$. six-hourly was substituted for chloramphenicol.

By 23/5/6I it became obvious that the meningeipis was not being controlled and the cell count had risen to 15,000. On this date the sensitivity of the organisonceo Penbritin was determined, the minimal inhibitory $\bar{c}$ as centration (MIC) being $2.5 \mu \mathrm{g} . / \mathrm{ml}$.; $500 \mathrm{mg}$. of P.enbritin were given orally and continued six-hourly. Penbritin level in the CSF at midday on $24 / 5 / 6 \mathrm{r}, \mathrm{i}$. six hours after the third dose, was $2.42 \mu \mathrm{g} . / \mathrm{ml}$. Tसle patient remained pyrexial, confused and restless and therefore it was decided to inject the drug intrathecally despite the fact that it had not previously been given by this route. The preparation used was a $2 \%$ solution of Penbritin in pyrogen-free distilled water brought to $\mathrm{a} \mathrm{pH}$ of 7.3 with freshly made $\mathrm{N} / \mathrm{r}$ sodium hydroxide. The solution was sterilized by filtration.

A test dose of $10 \mathrm{mg}$. was introduced into the theca at midday on $24 / 5 / 6 \mathrm{I}$, giving an approximate C level of $100 \mu \mathrm{g} . / \mathrm{ml}$. No ill-effects were observed a âd six hours later the CSF level of Penbritin was I2 $\mu \mathrm{g} . / \mathrm{ml}$., the cell count having risen to 17,000 . A further $20 \mathrm{mg}$. of Penbritin were then given intrathecality, there again being no sign of increased cerebral irritation. By the morning of $25 / 5 / 6 \mathrm{r}$ slight clinical improveme had occurred.

Intrathecal Penbritin was continued, $20 \mathrm{mg}$. twice daily, in addition to $500 \mathrm{mg}$. of the oral preparation six-hourly until 29/5/6I. The intrathecal dose wains then raised to $40 \mathrm{mg}$. twice daily, as the sensitivity rof the $E$. coli had decreased, the MIC of the organism being $12.5 \mu \mathrm{g} . / \mathrm{ml}$. Clinically the patient's condition improved, the confusion being less, the temperature settled and the meningism subsided.

The cerebro-spinal rhinorrhœa persisted and क्. $5 / 6 / 6 \mathrm{I}$, as the CSF was sterile, craniotomy was carrigd out by Mr. L. S. Walsh, with a view to closing the leak. At operation no fracture of the anterior fossa could Be detected and the dura appeared intact. As, however, the leak had been consistently from the left nostril gt was thought that this may have been through the le side of the cribriform plate. The left olfactory trapt and bulb were removed and the olfactory groove plugged 
WHITE CELLS

IN C.S.F
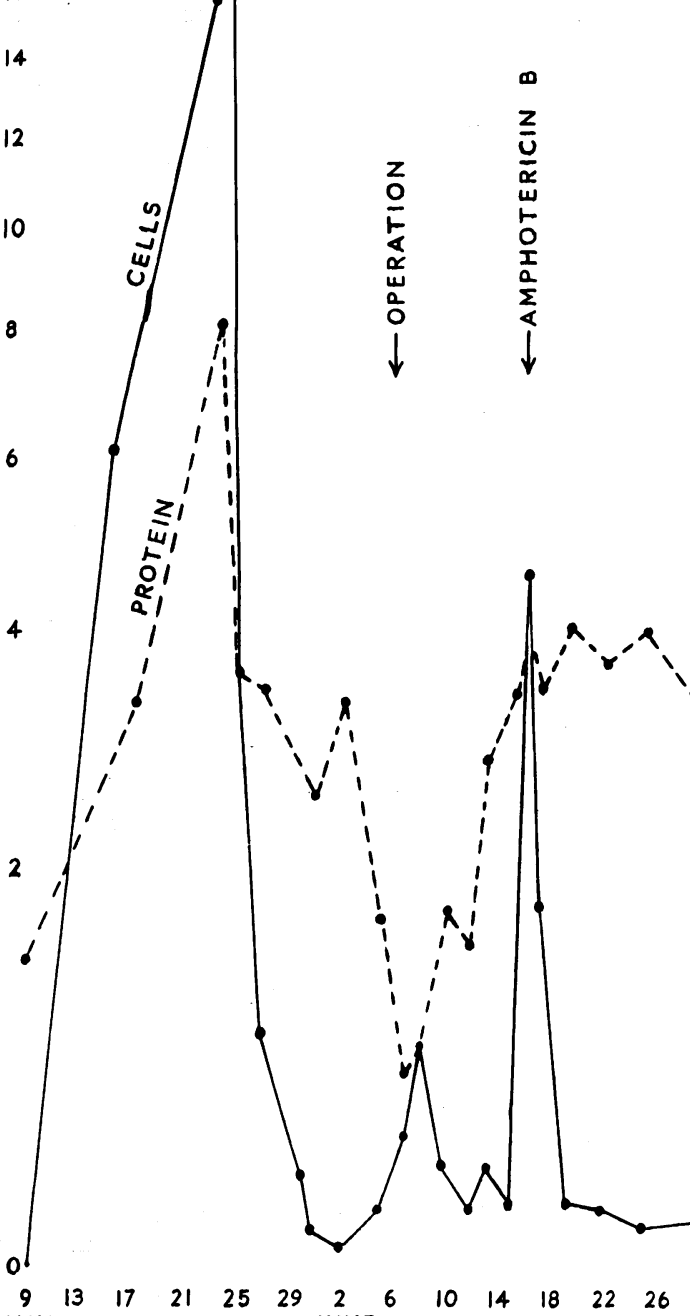

MAY

FIG. 1.-Graph showing the effect of combined oral and intrathecal Penbritin on the C.S.F. protein and cell count.

with Oxycel. The immediate post-operative period was uneventful and there was no further leakage of CSF. As $E$. coli had not been isolated since $28 / 5 / 6 \mathrm{r}$, Penbritin was discontinued on $14 / 6 / 61$.

On 6/6/6r a growth of Candida albicans was obtained from the CSF for the first time and it was isolated from specimens taken on five of the next six days. In addition the organism was found in a throat swab and in the stools. As persistent positive cultures were being obtained and the cell count had also risen in the CSF, it was considered that monilia meningitis had supervened.

Amphotericin B. has been used intravenously (Seabury and Dascomb, 1958) and it was shown that therapeutic levels of the drug could not be obtained in the CSF. The highest CSF level attained using the intra- venous route was $0.46 \mu \mathrm{g} . / \mathrm{ml}$. following $0.54 \mathrm{mg} . / \mathrm{kg}$. i.v., and the MHC of our patient's organism was 20 $\mu \mathrm{g} . / \mathrm{ml}$. We were therefore obliged to use the drug intrathecally. On $15 / 6 / 6 \mathrm{I}, 0.5 \mathrm{mg}$. of amphotericin B. reconstituted in $5 \%$ dextrose, was diluted with $3 \mathrm{ml}$. of CSF, making a total volume of $5 \mathrm{ml}$. "This was slowly introduced into the lumbar theca. There were no immediate toxic effects, but six hours following the injection he had several rigors and the temperature rose to $104^{\circ} \mathrm{F}$. The following day he remained pyrexial with cyanosed extremities, the blood pressure remaining at $150 / 90$. The CSF was not under-increased pressure but the cell count had risen to 4,300 and the sugar was only $12 \mathrm{mg}$. $/ 100 \mathrm{ml}$.

In view of the possibility that the $E$. coli infection might have recurred, Penbritin was again administered. 
TABle I

CSF and Blood Penbritin Levels

\begin{tabular}{|c|c|c|c|}
\hline & $\begin{array}{c}\text { CSF } \\
\text { level } \\
(\mu \mathrm{g} . / \mathrm{ml} .)\end{array}$ & $\begin{array}{c}\text { Serum } \\
\text { level } \\
(\mu \mathrm{g} . / \mathrm{ml} .)\end{array}$ & $\begin{array}{l}\text { Hours after } \\
\text { previous } \\
\text { injection }\end{array}$ \\
\hline $24 / 5 / 6 I$ & 2.42 & 0.43 & - \\
\hline $25 / 5 / 6$ I (a.m.) & $3 \cdot 3$ & o. & 12 \\
\hline 25/5/61 (p.m.) & 3.I & & 12 \\
\hline $26 / 5 / 6$ I (a.m.) & $4 \cdot 3$ & & 12 \\
\hline 26/5/6 I (p.m.) & 18.8 & & 12 \\
\hline $27 / 5 / 6$ I (a.m.) & 6.5 & & 12 \\
\hline 27/5/6r (p.m.) & 8.0 & & 12 \\
\hline $28 / 5 / 6$ I (a.m.) & 2.9 & & 12 \\
\hline 29/5/6I (a.m.) & 8.8 & & 12 \\
\hline 30/5/6r (a.m.) & $\mathrm{x} .84$ & & 24 \\
\hline 30/5/6r (p.m.) & 9.6 & & 12 \\
\hline $3 \mathrm{I} / 5 / 6 \mathrm{r}$ (a.m.) & 12.8 & & 12 \\
\hline
\end{tabular}

By 17/6/6r the pyrexia had subsided and subsequent CSF cultures were completely sterile. In fact, amphotericin was only given on a single occasion. By 26/6/6 I further improvement had occurred and Penbritin was discontinued.

Over the course of the next four weeks the patient's general condition improved and he put on over a stone in weight. Spikes of fever continued to occur, however, with coincidental elevation of the cell count in the CSF which remained consistently high (above I00/ cu. mm.). On $24 / 7 / 6$ I ventriculography was carried out to exclude the presence of a residual localized collection of pus. On inserting the brain cannula the intraventricular pressure was found to be raised, the lateral ventricles were symmetrically markedly dilated, as were the third and fourth ventricles, and little if any air left the fourth ventricle.

Unfortunately, progress was not maintained and over the weeks that followed he became progressively more apathetic, occasionally vomiting, giving only a very limited verbal response and showing little spontaneous activity. On examination at the time of transfer to another hospital there was slight bulging over the burrholes but no papillodema. He showed moderately severe signs of brain-stem damage, there being marked defect of conjugate gaze, inequality of the pupils, dysarthria and a brisk jaw-jerk. The right hemiparesis was still improving, but superimposed upon the pyramidal signs there was ataxia of the right arm, out of proportion to the clumsiness one would expect with a hemiparesis of this order. Both plantar responses were extensor.

\section{Discussion}

The internal hydrocephalus resulting from obstruction to the circulation of the CSF partially explained the clinical condition. Ventriculography excluded the presence of a sizeable collection of pus which would have accounted for the high cell count in the CSF. Residual basal meningitis remained a possibility, although no organism could be isolated. A foreign-body reaction to the Oxycel inserted at operation would not be expected to produce a high cell count in the CSF over a long period.

In spite of the occurrence of this unfortunate sequel of Monilia meningitis, it is fair to say that
Penbritin in this patient undoubtedly controlled hîn infection, for without it there can be no doubt that he would have perished during the acute menirog gitic stage.

The improvement was reflected in the rapic disappearance of pus cells from the CSF. With I 3 days of the commencement of treatment he wass fit for operation. Had his post-operative convalescence not been interrupted by the appearance of monilia, there is every reason to suppose that he would have made a more complete recover. The monilia infection presumably arose from his nose through a crack in the cribriform plate, since the organism had been isolated from the throa, and was a very unfortunate complication, being one of the few organisms not touched by theg various antibiotics he was given.

Over the course of five days, the MIC of the strain of $E$. coli rose from $2.5 \mu \mathrm{g} . / \mathrm{ml}$. to $12.5 \mu \mathrm{g} . / \mathrm{mg}$ : Doubling the intrathecal dose produced no un toward effects and the CSF was sterilized on thes dosage. It is not known what the maximum tolerated dose of Penbritin is, intrathecally. Pens britin, with its apparent complete lack of toxicity and its prompt action, clearly merits further trial in the treatment of meningitis caused by Gram. negative organisms.

Our patient was given twice-daily intrathec?l injections of Penbritin. This is probably not essep tial in a straightforward meningitis, if there is no leakage of CSF, but further investigatio required into the maintenance of drug level in the CSF in an uncomplicated case.

\section{Summary}

A case of $E$. coli meningitis is described, conoplicating a head injury. Treatment with systemic and intrathecal Penbritin cleared the CSF of infection by the Gram-negative bacillus. The role of the drug in the treatment of intracrang infections is discussed.

Our thanks are due to Mr. Wylie McKissock and Mr. L. S. Walsh, under whose care this patient was admitted, for permission to publish; to Prof. Eles, St. George's Hospital Medical School, for his advice; to Dr. Peter Croydon of the Beecham Research Laboratories for supplies of the drug and for estimating the serum and CSF levels; to Mr. G. Ellis for considerabe technical help; and to Miss Araminta McKissock for secretarial assistance.

\section{Addendum}

Since writing this paper we have treated $\mathrm{C}_{\mathrm{a}}$ further case of $E$. coli meningitis following head injury and CSF leak. The organism was sensitioge only to ampicillin, kanamycin and nitrofurantoiy. Over a period of 12 days his CSF cell count fell from 44,000 to I70 per cu. mm. and the CSF was stepilized. His MIC to Penbritin was $5 \mu \mathrm{g} . / \mathrm{ml}$. The dosage of Penbritin used was $500 \mathrm{mg}$. six-hourb, orally, and $40 \mathrm{mg}$. daily, intrathecally.

Corresponding with the fall of the cell counf, 
the sugar, which was initially less than $5 \mathrm{mg}$./100 $\mathrm{ml}$., rose to $72 \mathrm{mg}$./ $100 \mathrm{ml}$. Again no serious sideeffects were noted.

In spite of the apparent good initial response to
Penbritin, the patient subsequently died. At autopsy he was found to have a pocket of pus in his posterior fossa from which the organism was isolated.

\title{
REFERENCES
}

Brown, D. M., and ACred, P. (1961): 'Penbritin '-a New Broad Spectrum Antibiotic, Brit. med. F., ii, I97.

KNudSen, E. T., Rolinson, G. N., and STEvens, S. (1961): Absorption and Excretion of 'Penbritin', Ibid., ii, r 98, Rolinson, G. N., and Stevens, S. (196I): Microbiological Studies on a New Broad Spectrum Penicillin - 'Penbritin', Ibid., ii, $19 \mathrm{r}$.

SeabuRY, J. H., and Dascomb, H. E. (1958): Experience with Amphotericin B for the Treatment of Systemic Mycoses. Arch. intern. Med., 102, 960.

Stewart, G. T., Coles, H. M. T., Nixon, H. H., and Holt, R. J. (196r): ' Penbritin': An Oral Penicillin with Broad Spectrum Activity, Brit. med. F., ii, 200.

\section{PERNICIOUS ANAEMIA IN A YOUNG ADULT}

\author{
Sidney SHAw, M.D.(LoND.) \\ Reader in Hamatology and Consultant Hamatologist
}

J. G. LewIS, M.D.(LoND.), M.R.C.P. Senior Medical Registrar

Charing Cross Hospital and Medical School, London, W.C.2

Pernicious an emia is rare in young adults. Davis (1944) reviewed six large series of patients diagnosed as pernicious anæmia and, out of a total of 1,532 , only four were below the age of 20 years; the inadequacy of data necessary for a diagnosis of Addisonian anæmia in most of the cases previously described in young patients was noted. Wilkinson (1949) found an incidence of $2.8 \%$ of patients less than 30 years of age among 1,600 when first diagnosed; only one patient was under 21 years, and $67 \%$ were over the age of 50 years. Davidson (1952) in his Edinburgh series of 135 patients (1944-48) recorded $42 \%$ between the ages of 60 and 80 years when diagnosed. He later (1957) gave an incidence of over $50 \%$ occurring over 60 years of age in 100 cases (1950-56). Lambert, Prankerd and Smellie (196I) reviewed earlier publications on pernicious anæmia in childhood. They considered malabsorption of importance in the differential diagnosis and observed that fat-balance tests had been carried out in very few cases; the demonstration of intrinsic-factor deficiency is essential for the true diagnosis of pernicious anæmia, and they noted that in previous reports this examination had very rarely been carried out; in only four cases amongst those previously recorded was there adequate evidence of absence of intrinsic factor together with a satisfactory response to antipernicious anæmia therapy. They reported three recent cases diagnosed by modern techniques using labelled vitamin $\mathbf{B}_{12}$. The authors similarly investigated two further cases of juvenile pernicious anæmia in siblings, and referred to a further similar report on two siblings by Leikin (r960).
Recently, Metz, Randall and Kniep (I96r) described three cases of pernicious anæmia in young Bantu females.

Owing to the rarity of this condition in the young and the importance of precise diagnosis it was considered worthwhile to record the following case; according to our records this is the first such case below the age of 25 years to be admitted to this hospital during the last 14 years.

\section{Case Report}

N.M., an unmarried Irish woman aged 24 years, was admitted to this hospital in December 1960 with . weakness of the legs and difflculty in walking. She had been a barmaid until one year before; her alcoholic intake had been ' several shorts on two or three nights a week' and she usually smoked 20 to 30 cigarettes a day. Her father died at 42 years of age of diabetes mellitus and a paternal aunt also had diabetes mellitus. There was no family history of anæmia.

During the last year she had noticed shortness of breath on exertion with slight swelling of the ankles in the evenings; there was also a cough with a little yellow sputum. Her appetite was poor, there was no indigestion but she complained of increased thirst.

Three months before admission she saw her doctor with backache and painful frequent micturition; this was treated firstly with sulphonamides and finally responded fully to injections of streptomycin for 12 days.

One month before she had gone to bed with 'flu'; she had pyrexia, backache and aching all over. There was no further frequency of micturition but she thought her urine was cloudy and 'chocolate' coloured, and this appearance gradually cleared after about two weeks. One week after being in bed she stated that she suddenly became numb from the waist downwards and could not walk properly - she fell twice and felt as though 